\title{
Research diversity in accounting doctoral education: survey results from the German-speaking countries
}

\author{
Christoph Pelger ${ }^{1} \cdot$ Markus Grottke $^{2}$
}

Received: 4 March 2015/Accepted: 21 April 2017/Published online: 4 May 2017

(C) The Author(s) 2017. This article is an open access publication

\begin{abstract}
US positivistic accounting research is increasingly perceived as having come to be the point of reference for researchers in other countries, including the German-speaking area where formerly normative research was widespread. In this paper, we present the survey results retrieved from 293 doctoral students in accounting in 2009, a period of transition in which old and new approaches to doctoral education co-existed. Specifically, doctoral students were subject to institutional change in the form of more structured doctoral studies and a focus on internationalisation and attempts to publish in academic journals. We find that at that time there was diversity with regard to both the set of accounting journals considered by doctoral students and the methods employed by the latter in their dissertations. With respect to research methods, we show that factors of the institutional setting reflecting a more structured and international approach to doctoral education are in particular linked to empirical quantitative, and to a lesser extent qualitative, research.
\end{abstract}

Keywords Accounting journals · Accounting research · Doctoral education · German-speaking countries · Research diversity · Research method

Electronic supplementary material The online version of this article (doi:10.1007/s40685-017-0046y) contains supplementary material, which is available to authorized users.

Christoph Pelger

christoph.pelger@uibk.ac.at

Markus Grottke

markus.grottke@hs-calw.de

1 Department of Accounting, Auditing and Taxation, University of Innsbruck, Universitätsstr. 15, 6020 Innsbruck, Austria

2 Financial and Management Accounting, SRH Hochschule für Wirtschaft und Medien, Lederstraße 1, 75365 Calw, Germany 
JEL Classification M41 · M42 · M49

\section{Introduction}

Recently, researchers have repeatedly claimed that the US mainstream approach to accounting research, which has been characterised by the dominance of positivistic approaches that focus on economic perspectives and that are mostly limited to largescale archival studies (Williams et al. 2006; Oler et al. 2010), has increasingly begun to influence accounting research in other parts of the world (Hopwood 2007; Khalifa and Quattrone 2008; Lukka 2010). Such concerns have been raised with respect to alternative paradigms emphasising sociological or philosophical perspectives on accounting, paradigms that are often subsumed under the term "critical-interpretive school" (Chua 1986; Ahrens et al. 2008) and that have been influential in countries such as the UK, Australia or New Zealand (Locke and Lowe 2008).

In the German-speaking countries, accounting research has traditionally followed a normative or conceptual approach (e.g. Fülbier and Weller 2008; Messner et al. 2008). Due to strong links between accounting academia and practice, the main purpose of accounting research was to provide insights into and recommendations to practice, for example with respect to interpretations of German accounting law (Küpper and Mattessich 2005; Fülbier and Weller 2008; Messner et al. 2008). However, in recent years empirical accounting research has become more prominent in the German-speaking countries (Perrey et al. 2010; Messner et al. 2008; Lohmann 2012) and literature has claimed that there is an ongoing trend towards US-type positivistic research (Fülbier and Weller 2008; Schäffer 2013).

In spite of such claims, as yet there is little empirical evidence on the extent to which the US mainstream spreads to other countries and the way in which its dissemination is linked to the (local) institutional setting. In this context, our paper scrutinises research diversity and its relations to the institutional environment in the German-speaking area during a period of transition. The definition of research diversity employed in this paper covers two dimensions: accounting journals and research methods. The former dimension finds its justification in journal publications being perceived as the most important output of accounting academics as they form the basis for decisions concerning tenure, promotion or funding (Lee 2004; Gendron 2008; Pelger and Grottke 2015). As a result, "accounting journals are the critical element in the social structure of the discipline" (Schwartz et al. 2005, p. 330). Locke and Lowe (2008) show that academic accounting journals differ with respect to their paradigmatic position. They differentiate between journals following functionalist (positivistic) and critical-interpretive paradigms (for this distinction also see Chua 1986; Chapman 2012). In our study, considering the tradition of accounting research in the German-speaking area, in addition to positivistic and critical-interpretive journals, we also take up German journals in business economics that reflect the traditional local paradigm with a focus on normative research (Fülbier and Weller 2011; Lohmann 2012; Wagenhofer 2006). Our study explores the extent of diversity in terms of awareness of a set of different accounting 
journals and the quality attributed to these outlets. In addition to considering a set of different accounting journals, as a second indication of research diversity we focus on the research methods employed (e.g. also see Williams et al. 2006; Oler et al. 2010). In identifying specific research methods, we follow the classification by Grochla (1976) and distinguish between verbal-analytical, ${ }^{1}$ empirical and analytical modelling approaches. We further divide empirical research into quantitative and qualitative approaches. ${ }^{2}$

For our study into research diversity we focus on one specific group of academics that "may be the least studied group of individuals in the universe of the accounting discipline" (Fogarty and Jonas 2010, p. 303): doctoral students. For two reasons the latter are a particularly interesting group to study. First, the extent of diversity among those doctoral students who remain in the academy after finishing their $\mathrm{PhD}$ is one indicator of the extent of the future diversity in the academy. Second, doctoral education in accounting (and business economics more generally) has recently been subject to major changes in the German-speaking countries. In particular, the introduction of more structured approaches to doctoral education and the emphasis being put on internationalisation and publication activities have changed the form and content of doctoral education in accounting (Pelger and Grottke 2015, 2016).

The present paper aims at understanding the status quo at a time at which these changes were still ongoing and, by considering the context of the institutional setting, attempts to derive implications for research diversity. More specifically, we present explorative empirical findings on the basis of the data retrieved from an online survey among 293 accounting doctoral students from the German-speaking area in autumn 2009. Our study provides a snapshot of research diversity at a particular point in time at which doctoral education was in transition from a traditional model towards a more structured model (Djelic 2008). That the year of our survey reflected a period of transition can most clearly be seen in the fact that the German Academic Association for Business Research (VHB) started its structured doctoral program (ProDok) in 2009 (VHB 2009). Developed with the intention to complement programs at individual universities by offering specialised courses, inter alia in accounting (VHB 2016), the VHB highlights that "with ProDok, the VHB is looking to make it easier for its doctoral students to succeed among the international research competition" (VHB 2016). Moreover, during this time period several broader changes took place that affected accounting academia in the German-speaking area, such as the implementation of the Bologna reform and the rising importance of internationally common performance evaluation criteria (Wissenschaftsrat 2002;

\footnotetext{
1 Verbal-analytical research generally includes both conceptual discussions and normative analyses of accounting topics. Traditionally, in financial accounting this research method has been strongly linked with the use of normative analyses (for the distinction of positivistic and normative accounting research e.g. cf. Fülbier and Weller 2008).

${ }^{2}$ We note that qualitative empirical research might be conducted by following positivistic or criticalinterpretive paradigms (Malsch and Salterio 2016). However, leading positivistic accounting journals publish almost no qualitative research (e.g. Oler et al. 2010). Likewise, quantitative methods are rarely used in research pursuing critical-interpretive agendas (Richardson 2015).
} 
DFG 2012; Kieser 2012). ${ }^{3}$ Our survey data enable us to investigate doctoral students' perceptions of a set of accounting journals and method choices at a time of a (local) scientific revolution (Kuhn 1996) and to also explore links to factors that reflect the institutional environment of doctoral education.

Hence, we address the following research questions:

1. How are different accounting journals taken into account and assessed by doctoral students?

2. What is the extent of diversity in the research methods adopted by accounting doctoral students in their dissertations?

3. How are characteristics of the doctoral education setting related to the research methods used by doctoral students in accounting? How is the research method employed associated with doctoral students' familiarity with different accounting journals?

First, we focus on the extent to which doctoral students in German-speaking countries are familiar with a set of accounting journals and how they assess the quality of the journals. We show that familiarity with US mainstream journals, European Accounting Review (EAR) and German academic journals is high, while familiarity with Accounting, Organizations and Society (AOS) and, in particular, Critical Perspectives on Accounting (CPA) is far more limited. With regard to the second research question our study reveals that doctoral students in the Germanspeaking setting use various different methods and that many doctoral students approach their topics with the aid of multiple methods. At the same time, our analysis provides some indications that the structured approach to doctoral education, which goes hand in hand with an emphasis on internationalisation, seems to be primarily related to the adoption of quantitative empirical methods. While empirical qualitative doctoral researchers also tend to be internationally oriented, their absolute number remains relatively small. The number of students pursuing verbal-analytical approaches is still substantial at the time of our survey, but these doctoral students are less related to features of more structured and international doctoral education.

Our study is related to two streams of literature. First, this paper contributes to the critical debate on current trends in accounting research and on the risk of homogeneity triumphing on a global scale (e.g. Hopwood 2007; Khalifa and Quattrone 2008; Lukka 2010) and follows the appeals voiced by Hopwood (2008) to sustain debate on the issues at stake. Part of this literature has focussed on the socialisation of $\mathrm{PhD}$ students, however, mostly in US accounting academia (Schwartz et al. 2005; Fogarty and Jonas 2010). The paper by Schwartz et al. (2005) is closest to our study as the authors present the results of a survey they carried out in fall 1999 among 151 accounting students from selected US doctoral programs. They were primarily concerned with the exposure of US doctoral students to different paradigms in accounting research and thus asked doctoral students how

\footnotetext{
${ }^{3}$ While reflecting longer-term developments, at that time traditional German accounting research was also perceived as increasingly giving way to positivistic research (e.g. Fülbier and Weller 2008; Messner et al. 2008).
} 
familiar they were with 37 accounting journals. Their main finding is that US doctoral students state to be very familiar with the three top mainstream accounting journals [The Accounting Review (TAR), Journal of Accounting Research (JAR), Journal of Accounting and Economics (JAE)], but that AOS enjoys only an average degree of familiarity, while all other non-mainstream journals are largely unknown. Our paper carries out a similar survey for doctoral students in accounting in the German-speaking countries which also aims at understanding the familiarity of doctoral students with different research discourses. However, we extend the approach by Schwartz et al. (2005) as we also consider research methods adopted by doctoral students and relate these to the institutional setting of doctoral education. This enables us to provide more comprehensive observations of research diversity and its relation to certain features of the institutional environment which we use to derive implications for how research diversity might be sustained and fostered.

Second, our paper contributes to literature that sheds light on doctoral education in accounting in the German-speaking area. In their reflective essay, Pelger and Grottke (2015) discuss the repercussions of internationalisation and performance orientation on doctoral students based on their personal experiences and then relate this situation to more general developments in German-speaking accounting academia. Two papers use data from the same survey as the present paper: first, Pelger and Grottke (2016) provide a number of indications that doctoral education moves from a traditional towards a more structured model of doctoral education, which relates in particular to many students attending doctoral courses and participating in international conferences. We link doctoral students' choice of research methods to this changed institutional setting of doctoral education in Sect. 3.3. Pelger and Grottke (2016) also analyse which factors determine doctoral students' satisfaction with their supervision and with their doctorate as a whole. ${ }^{4}$ Second, Grottke et al. (2013) analyse differences between doctoral students who want to stay in accounting academia and those who prefer to go into business practice after finishing their doctorate. The authors find that attitudes which might be typically related to ideal type academics are not generally more pronounced among doctoral students with the desire to stay in academia. However, the latter group feels the effects raised by recent changes to performance orientation in academia more strongly in that they are more active on an international level and feel higher pressure to publish than future practitioners. Different from these studies, the focus of this paper is on research diversity as exhibited in doctoral students' familiarity with different accounting journals and their method choice and on how this is related to factors of the institutional environment.

The paper is structured as follows: in Sect. 2, we describe the design of the survey and introduce the relevant variables. Section 3 presents the results of our survey of German-speaking doctoral students and discusses the limitations of this study. Section 4 offers a summary and a discussion of our results, while Sect. 5 explores possible wider implications of our findings.

\footnotetext{
4 The authors show that doctoral students' satisfaction with the supervision is enhanced by regular meetings and substantial input by the supervisor, while their general satisfaction with their doctorate is primarily driven by the satisfaction with the supervision and enhanced, for instance, by conference participations and publications. Focusing on the perspective of professors in business economics, Weber and Kaminski (1995) present survey results on professors' perceptions of doctoral students and doctoral education.
} 


\section{Survey design and definition of variables}

We carried out a perception study among German-speaking doctoral students, using a web-based survey (for this approach see, for example, Lowe and Locke 2005). In developing the questionnaire, we conducted two rounds of pre-testing with survey experts, doctoral students from other disciplines and members of accounting faculties. A manual internet search was used to identify all the chairs related to management accounting or financial accounting/auditing ${ }^{5}$ at universities in the German-speaking area. ${ }^{6}$ We found 150 chairs in autumn 2009 . The population of doctoral students, as assessed on October 1st, 2009, consisted of 782 doctoral students ${ }^{7}$ mentioned on the websites. ${ }^{8}$ Thus, at that time on average each professor (chairholder) in our sample supervised about five doctoral students. ${ }^{9}$ In October 2009, we sent an initial invitation to take part in the survey ${ }^{10}$ and we reminded those who had not yet participated on three occasions after 3 weeks had elapsed, respectively. All the participants remained anonymous. In total, 293 doctoral students completed the questionnaire, which amounts to a response rate of $38.45 \%$ - a result which, compared to other recent surveys carried out in accounting academia, is acceptable (Brinn et al. 1996: 34.6\%, $n^{11}=90$; Lowe and Locke 2005: $16 \%, n=149$, Schwartz et al. 2005: $57 \%, n=151) .^{12}$

With a view to assessing the diversity of discourses consulted by doctoral students, we asked them about their familiarity with a set of journals and their perceptions of the latter's quality, thus combining to a certain degree the approaches

\footnotetext{
5 The keywords of the search included: financial accounting, management accounting, auditing and corporate governance.

${ }^{6}$ We included private and public universities. Polytechnics were not considered, as they do not have the authority to grant doctoral degrees.

7 It turned out that 20 email-addresses were invalid, which reduced our population to 762 doctoral students.

8 This approach excludes doctoral students in accounting who belong to graduate schools that might be separate from departments of accounting. However, as the number of graduate schools in business studies is quite small, and as only some of these students specialise in accounting, we do not expect a significant loss of data.

9 This ratio indicates that professors in the German-speaking area, on average, supervise more doctoral students than their colleagues in the UK or the US. For the UK, Beattie and Smith (2012, p. 23) show that there were $833 \mathrm{PhD}$ students in accounting in 2010 compared to 1400 potential PhD supervisors. For the US, Brink et al. (2012, p. 924) reveal an average enrolment of 9.62 students per PhD program. Given that an accounting department with a doctoral program in accounting usually has more than two accounting professors, the ratio also seems to be lower than in the German case. However, note that such comparisons have to be treated cautiously as the chair system in Germany is different from the department structures in the UK and the US.

${ }^{10}$ A translated version of the part of the questionnaire which has been used for this paper, information about data collection and the coding process as well as the data of the survey are available as additional online material to this paper. The questionnaire, in total, included about 60 questions concerned with a wide range of topics e.g. related to working conditions, supervision, career plans, research attitudes and interests, the conditions in which the respondents' research is done and its outcome.

11 The letter " $n$ " represents the number of actual participants in the respective survey.

12 As the number of participants exceeds the necessary threshold of 260 participants (Krejcie and Morgan 1970), our study does not suffer from possible representation bias.
} 
taken by Schwartz et al. (2005) and Locke and Lowe (2008). ${ }^{13}$ Against the background of these studies and the German journal ranking JOURQUAL2, ${ }^{14}$ we decided to include journals from the following groups; first, three journals standing at the top of the US mainstream were considered: JAR, JAE and TAR. There is little doubt that these journals belong to the positivist or functionalist school of accounting thought (Locke and Lowe 2008). Second, three internationally acknowledged journals were included which represent a more diverse approach to accounting research and which are more closely associated with non-US environments (Lukka and Kasaanen 1996; Qu et al. 2009): AOS, EAR and CPA. AOS and CPA, as assessed by accounting academics, represent the critical-interpretive school (Lowe and Locke 2005), while EAR is regarded as publishing papers from both positivistic and critical-interpretive perspectives (Locke and Lowe 2008). ${ }^{15}$ Finally, owing to the lack of German academic journals specialising in accounting (Wagenhofer 2006), we included the four German academic journals in general business economics, Zeitschrift für betriebswirtschaftliche Forschung (ZfbF), Zeitschrift für Betriebswirtschaft (ZfB), Die Betriebswirtschaft (DBW) and Betriebswirtschaftliche Forschung und Praxis (BFuP), ${ }^{16}$ that reflect the German accounting tradition with regard to publishing normative research, something which at the time of our survey still accounted for part of the journals' (accounting) content (Binder and Schäffer 2005; Perrey et al. 2010).

To validate our choice of journals, we asked the participants in an open question to indicate further journals with which they were very familiar (for a similar procedure see Weber and Stevenson 1981). Respondents mentioned a diverse set of

\footnotetext{
${ }^{13}$ Our approach differs from both studies, as we deemed it necessary to focus on a manageable set of journals for three reasons. First, the purpose of this paper is not to add a further ranking of accounting journals to the literature (for rankings of accounting journals e.g. see Ballas and Theoharakis 2003; Bonner et al. 2006; Wakefield 2008; Cook et al. 2010). Second, we tried to keep the questionnaire as short as possible so as to attract a higher response rate. Third, heterogeneity in assessing accounting journals increases with decreasing familiarity (Milne 2002) and increasing journal specialisation (Howard and Nikolai 1983; Weber and Stevenson 1981). Thus, we only included general accounting academic journals which (in principle) are not limited to specialist areas of accounting (such as management accounting). The journals used in our study make it clear in their aims and scope announcements on their websites that they cover "all areas of accounting research" (JAR) or that contributions are welcomed on "any accounting-related subject" (TAR).

${ }^{14}$ The JOURQUAL2 ranking is the second version (2008) of a ranking which was established by the VHB in 2004. The ranking is based on a survey of German-speaking business professors and assistant professors, while several adjustments based on the researcher's own publication activity were carried out. For details on the development of JOURQUAL2, see Schrader and Hennig-Thurau (2009).

${ }^{15}$ Note that EAR also has tended to publish research following local traditions, for example, normative research with a strong reliance on legalistic perspectives, the traditionally dominant form of Germanlanguage research in financial accounting (e.g. Ordelheide 1993; Kuhner 1997; Alexander and Eberhartinger 2009). Moreover, AOS also has published positivistic studies, in particular using experimental approaches (Oler et al. 2010).

${ }^{16}$ This approach is in line with the studies done by Perrey et al. (2010, 2012). The reasoning is as follows: $\mathrm{ZfbF}$ and $\mathrm{ZfB}$ were ranked as B-journals in JOURQUAL2, while DBW was considered a C-journal. BFuP is incorporated into our study, despite its status as a D-journal in JOURQUAL2, because it is a journal that particularly focuses on topics in accounting and is the only German management journal which is part of the international database SSCI (Social Science Citation Index). Besides, the studies by Binder and Schäffer (2005), Wagenhofer (2006), Messner et al. (2008) and Perrey et al. (2010, 2012) also include BFuP in their set of journals.
} 
more than 120 additional journal titles, the majority of which were practitioner journals. The following journals were mentioned more than ten times: Zeitschrift für kapitalmarktorientierte Rechnungslegung (16), Management Accounting Research (MAR) (13), Der Betrieb (12), Betriebsberater (12), Contemporary Accounting Research (CAR) (11), Journal of Finance (10), and Die Wirtschaftsprüfung (10). All German titles represent professional journals with a focus on financial accounting issues. Closest to this set of journals with seven mentions came the Academy of Management Journal. While the Journal of Finance is a finance journal and MAR is a specialist journal focusing on a sub-area of accounting (management accounting), which is thus not considered in our journal selection, the exclusion of CAR rests on the observation that CAR leaned relatively close to the US mainstream at the time of our survey (Macintosh 2004; Oler et al. 2010; Qu et al. 2009), which has already been reflected in our study via the inclusion of three major US journals. ${ }^{17}$ Following Schwartz et al. (2005) and Weber and Stevenson (1981) we included one more journal in the list-a journal which does not, in fact, exist (we labelled this journal Journal of Accounting and Institutions). All 28 participants who claimed to be at least to some extent familiar with this fictitious journal (a value larger than four on a seven-point scale) were excluded from our analysis regarding journal discourses, which reduces the sample for our analyses involving journals in Sects. 3.1 and 3.3 to 265 participants. ${ }^{18}$ In the questionnaire, we asked participants to provide their familiarity and quality assessments on a seven-point rating scale (e.g. also cf. Locke and Lowe 2008), ranging from one (not familiar at all; very bad quality) to seven (very familiar; very high quality). ${ }^{19}$

We distinguish the following research methods: analytical (mathematical) modelling, empirical (commercial (external) or self-created database, experiments, surveys, case studies, other) and verbal-analytical studies. As doctoral students are not limited to using only one method in their dissertation, we allowed for multiple responses which may, moreover, indicate the existence of overlaps between the different methods.

With regard to the institutional setting in which doctoral education takes place, we decided to focus on variables that reflect the development towards a more structured approach of doctoral education, as outlined, for example, by Pelger and Grottke (2015, 2016). A major change in doctoral education has been the

\footnotetext{
17 Note that an array of further international accounting journals of course exist, including e.g. Accounting, Auditing and Accountability Journal, Abacus, Accounting Education, Accounting Forum, Accounting and Business Research, Accounting Horizons, British Accounting Review. Moreover, there are other journals with a prestigious tradition in business economics from the German-speaking area, in particular the Journal für Betriebswirtschaft from Austria and Die Unternehmung from Switzerland. However, the answers to the open question mentioned above indicate that German-speaking doctoral students did not primarily read these outlets in 2009 .

18 Abbreviations for all the journals considered in our questionnaire are provided, together with their respective positions in the JOURQUAL2 ranking, in Table 8 in the "Appendix".

19 We randomised the sequence of journals. While we did not grant respondents the opportunity to withhold their assessment with regard to their familiarity with a journal, we did offer the option "Can't say" with respect to the quality of each journal. Moreover, before we even asked about participants' familiarity with specific journals, we asked whether they read English journals at all. Twenty participants replied that they did not read English journals, which reduced the scope of journals presented to them in the survey to the four German journals.
} 
introduction of structured course programs, which were unusual in the traditional model (Pelger and Grottke 2015). Hence, we consider the areas covered by the courses attended by doctoral students. Specifically, we asked whether students attended courses in statistics (Statcourse), economics (Econcourse) or psychology (Psychcourse), as these areas reflect courses that usually form part of US accounting doctoral programs (e.g. Lee 2004). A further change is the increasing interaction with the international research community (Pelger and Grottke 2016). Therefore, we assess the dimension of internationalisation with doctoral students' responses to the question of whether they attend conferences/workshops abroad (Confabroad) and whether they have completed or planned research stays abroad (Stayabroad). In line with internationalisation, a further trend which increasingly shapes doctoral education is an emphasis on publications in academic journals (Pelger and Grottke 2015). Thus, we asked whether doctoral students are writing a paper-based dissertation (Paperbased). Linked to the increasing focus on publication, we also asked whether they were aware of the JOURQUAL ranking (AwareJQ). Finally, we included variables that enable us to distinguish doctoral students in different groups, based on their specialisation (Management Accounting, Financial Accounting, Other) and their career preferences (Practice, Academia, Undecided).

\section{Results}

\subsection{Accounting journals}

Figure 1 provides insight into the familiarity and quality dimensions associated with journals, as perceived by German-speaking doctoral students. On the horizontal axis doctoral students' familiarity with the respective journals is shown, while the vertical axis reveals the doctoral students' perceptions of journal quality. The size of the bubble is determined by the number of participants that felt able to assess the quality of the journal. Table 1 shows differences in the familiarity levels and quality levels between journals.

German-speaking doctoral students state to be most familiar with the German academic journals. Among these, $\mathrm{ZfbF}$ and $\mathrm{ZfB}$ reach a broader readership than DBW and BFuP. This group of journals is followed in familiarity by the three top US journals and EAR, which all rank above the medium scale level of four. According to their statements, doctoral students are on average less familiar with AOS and they are least familiar with CPA.

With respect to the quality dimension, the three US journals are ranked highest, with JAR slightly ahead of TAR and JAE. ${ }^{20}$ AOS is nearly at the same level as TAR and JAE. ${ }^{21}$ German-speaking doctoral students have also a high regard for EAR, the

\footnotetext{
${ }^{20}$ While the differences between JAR and TAR and between TAR and JAE are not significant, there is a significant difference in the quality perception of JAR and JAE (see Table 1).

21 These four journals are commonly assigned the status of A-journals in journal rankings published in the accounting literature (e.g. Bonner et al. 2006; Chan et al. 2009). In the study by Locke and Lowe (2008), academics from the UK and Australasia ascribe the highest quality to AOS, while in most UScentred studies the top three US journals rank in the first three places (Chan et al. 2009).
} 


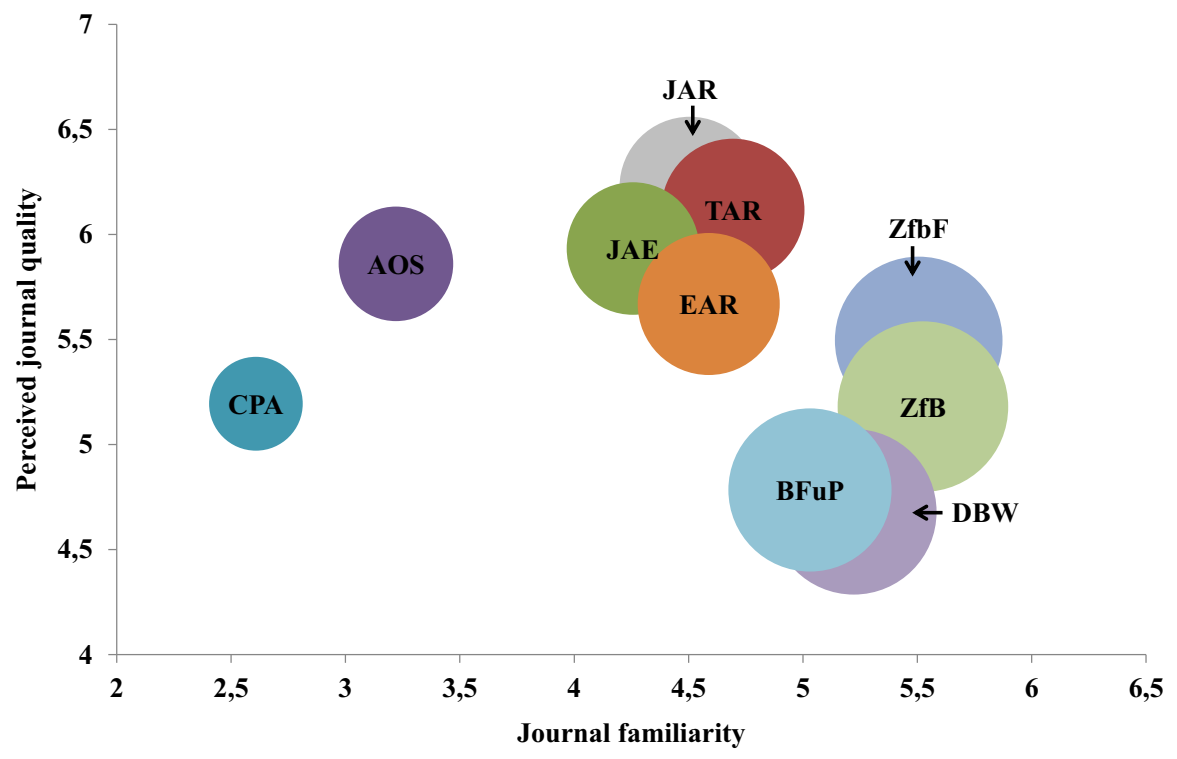

Fig. 1 Journal familiarity and perceived journal quality. This figure shows the journal familiarity and the perceived journal quality of doctoral students on a scale from one (not familiar at all; very bad quality) to seven (very familiar; very high quality). The size of the bubble reflects the number of participants who assessed the quality of the respective journal. Journal abbreviations are explained in Table 8 in the "Appendix"

quality of which is assessed similarly to AOS. Then, ZfbF, CPA and ZfB follow. ${ }^{22}$ The least good quality is attributed to BFuP and DBW. This assessment almost exactly resembles the journal ranking by the German Academic Association for Business Research at that time (JOURQUAL2). ${ }^{23}$

A closer look at correlations between journal familiarities (Fig. 2) shows that the stated knowledge of one top US journal usually entails the stated knowledge of the other two. Acquaintance with one German academic business economics journal often goes hand in hand with a high familiarity with the other German journals. An interesting finding from Fig. 2 is that EAR seems to play a bridging role between doctoral students familiar with US journals and those familiar with AOS.

Figure 3 reveals that the quality signals preserve the close connections of US mainstream and traditional German academic business economics journals, respectively. However, there are more diverse opinions on the quality of the other three journals.

\footnotetext{
${ }^{22}$ While the differences between $\mathrm{ZfbF}$ and $\mathrm{CPA}$ and between $\mathrm{ZfB}$ and CPA are not significant, there is a significant difference in the quality perception of $\mathrm{ZfbF}$ and $\mathrm{ZfB}$ (see Table 1).

23 In fact, the only difference with regard to the ordering of journals is that doctoral students on average ranked BFuP (JOURQUAL2: D) in front of DBW (JOURQUAL2: C). However, this difference is not significant (see Table 1).
} 


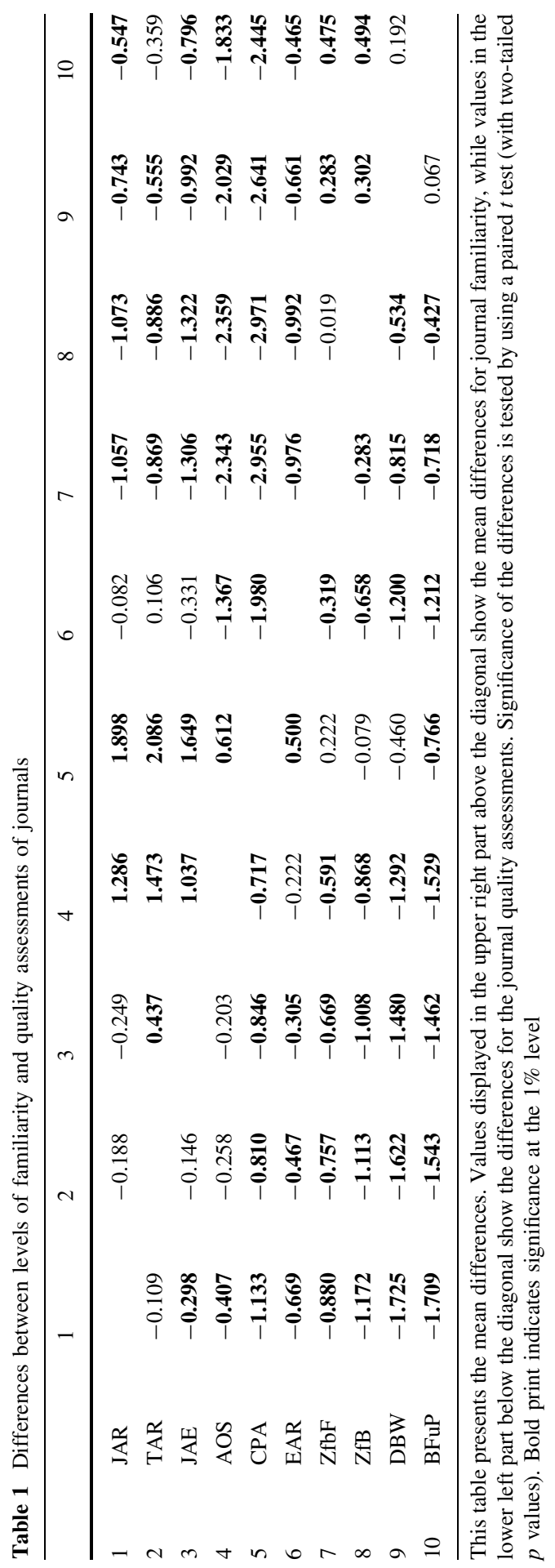



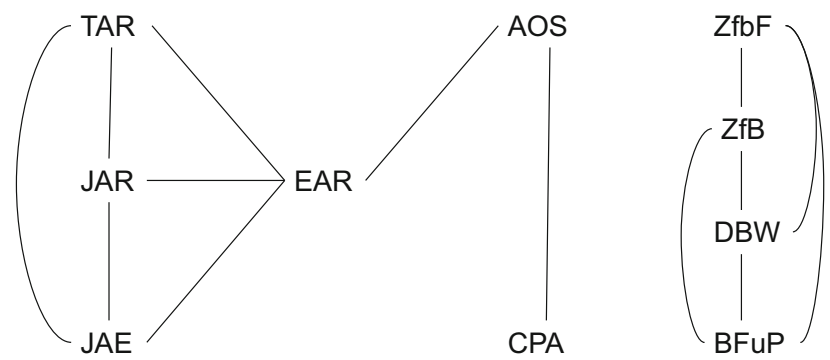

Fig. 2 Correlations of journal familiarity. This figure shows correlations of journal familiarity. Each line between the journal names indicates a correlation higher than 0.5 according to Table 4 . Journal abbreviations are explained in Table 8 in the "Appendix"
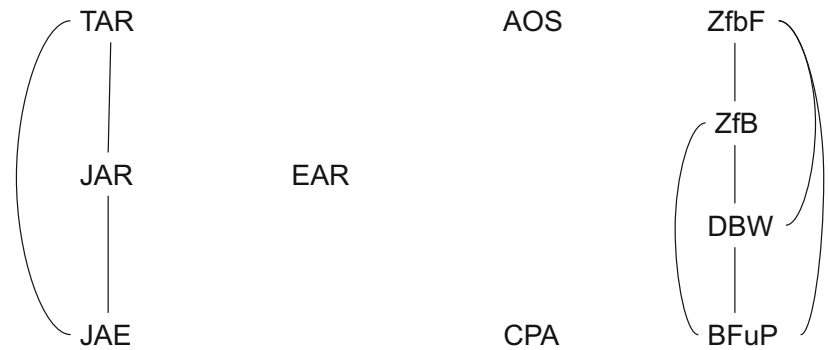

Fig. 3 Correlations of perceived journal quality. This figure shows correlations of perceived journal quality. Each line between the journal names indicates a correlation higher than 0.5 according to Table 4 . Journal abbreviations are explained in Table 8 in the "Appendix"

\subsection{Research methods}

Figure 4 shows the distribution of different methods among German-speaking doctoral students in 2009. It reads as follows: 140 doctoral students declare that they carry out verbal-analytical research, 64 (13) of whom likewise use empirical (analytical modelling) methods, while seven participants use analytical modelling, verbal-analytical and empirical approaches in their dissertations.

Figure 4 reveals that nearly two-thirds of doctoral students (also) use empirical methods in their dissertation. About half of the doctoral students surveyed employ verbal-analytical reasoning in their dissertations, while about a quarter of doctoral students use analytical modelling. It is notable that many doctoral students claim to employ more than one method in their dissertation.

Table 2, Panel A, reveals how the different methods are distributed among the different specialisations in accounting, distinguishing between financial accounting, management accounting and others. There are no significant differences between the groups with regard to verbal-analytical research and analytical modelling. Both financial and management accounting doctoral students are significantly more heavily involved in empirical research than the group of others. As for the specific empirical methods used, we find that surveys and case studies are the most common empirical methods used in management accounting. Archival research, based on 


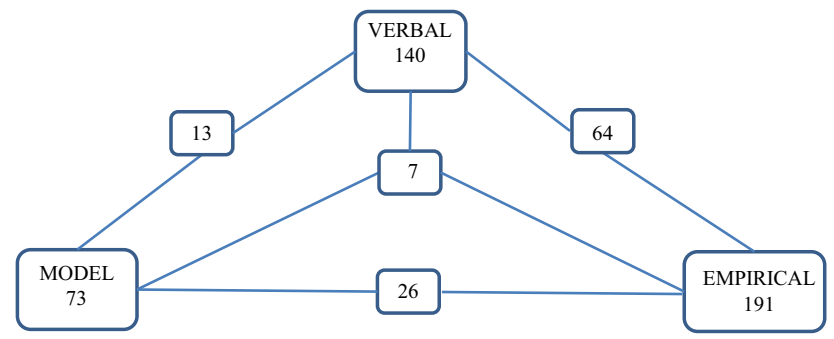

Fig. 4 Distribution of different methods

self-created or commercial databases, is the dominant empirical method in financial accounting. Experimental research is carried out by about $7 \%$ of doctoral students, with no major differences existing between the groups.

A look at different career paths in Table 2, Panel C, reveals a few differences in the specific type of empirical research adopted by some doctoral students. Doctoral students who would like to stay in academia are more likely to use commercial databases for their empirical research, while doctoral students who see their future in practice more often use surveys. Moreover, the table shows that no significant differences between career paths in academia and practice exist with respect to verbal-analytical research. In fact, nearly $60 \%$ of doctoral students aiming at a position in academia (also) employ verbal-analytical reasoning in their dissertation. Although this difference is not significant, it is also noteworthy that prospective academics tend to adopt multiple methods, while a larger proportion of doctoral students going into practice uses only a single method in their dissertations.

\subsection{Associations between journal familiarity, research method and the institutional setting of doctoral education}

Table 3 provides definitions of the variables that are used for the analysis of the institutional setting and provides descriptive statistics. Table 4 provides correlations between all variables used in this study. Tables 5 and 6 show univariate statistics about doctoral students' journal familiarity (Table 5) and factors of the institutional setting (Table 6), distinguished by research area (Panel A) and research method (Panel B). ${ }^{24}$ With regard to specialisations, in Table 6, Panel A, many items do not differ significantly between the groups. For example, the percentage of doctoral students writing paper-based dissertations and the awareness of the JOURQUAL ranking are all very similar across the groups. However, there are some notable differences with respect to journal familiarity (Table 5, Panel A): while

\footnotetext{
${ }^{24}$ Here we distinguish between verbal-analytical $(n=140)$, empirical quantitative $(n=103)$, i.e. use of (commercial and/or self-created) databases or experiments, empirical qualitative $(n=31)$, i.e. use of field/case studies, and analytical modelling $(n=73)$ approaches. We did not assign the survey method to quantitative or qualitative research because this depends at least in part on the type of questions (open vs. closed questions) and the number of respondents. Note that owing to the substantial number of doctoral students using multiple methods, statistical significance in Panel B of Tables 5 and 6 does not reflect differences between the different methods but differences between doctoral students who employ a certain method (e.g. verbal-analytical research) and those who do not.
} 
Table 2 Research methods

\begin{tabular}{|c|c|c|c|c|c|c|c|c|}
\hline$N$ & $\begin{array}{l}\text { Fin. } \\
\text { Acc. } \\
121 \\
\text { Mean }\end{array}$ & $\begin{array}{l}\text { Man. } \\
\text { Acc. } \\
125 \\
\text { Mean }\end{array}$ & $\begin{array}{l}\text { Other } \\
47 \\
\text { Mean }\end{array}$ & $\chi^{2}$ & $\begin{array}{l}\text { Academia } \\
37 \\
\text { Mean }\end{array}$ & $\begin{array}{l}\text { Practice } \\
177 \\
\text { Mean }\end{array}$ & $\begin{array}{l}\text { Undecided } \\
79 \\
\text { Mean }\end{array}$ & $\chi^{2}$ \\
\hline & \multicolumn{4}{|c|}{ Panel A: Distinction by research area } & \multicolumn{4}{|c|}{ Panel C: Distinction by future career path } \\
\hline Verbal-analytical & 0.54 & 0.41 & 0.51 & 4.34 & 0.59 & 0.47 & 0.44 & 2.45 \\
\hline $\begin{array}{l}\text { Analytical } \\
\text { modelling }\end{array}$ & 0.24 & 0.24 & 0.30 & 0.71 & 0.24 & 0.24 & 0.28 & 0.50 \\
\hline Empirical & 0.67 & 0.70 & 0.49 & $6.68 * *$ & 0.70 & 0.67 & 0.59 & 1.72 \\
\hline Case study & 0.04 & 0.20 & 0.02 & $20.52 * * *$ & 0.16 & 0.11 & 0.06 & 2.84 \\
\hline Survey & 0.21 & 0.46 & 0.13 & $25.03 * * *$ & 0.22 & 0.35 & 0.24 & $4.63 *$ \\
\hline $\begin{array}{l}\text { Self-created } \\
\text { database }\end{array}$ & 0.32 & 0.10 & 0.04 & $28.39 * * *$ & 0.22 & 0.16 & 0.20 & 0.91 \\
\hline $\begin{array}{l}\text { External } \\
\text { database }\end{array}$ & 0.32 & 0.10 & 0.23 & $18.98 * * *$ & 0.35 & 0.18 & 0.23 & $5.85 *$ \\
\hline Experiment & 0.08 & 0.05 & 0.11 & 2.12 & 0.08 & 0.04 & 0.14 & $8.19 * *$ \\
\hline \multirow[t]{2}{*}{ Other } & 0.02 & 0.04 & 0.02 & 0.64 & 0.08 & 0.03 & 0.00 & $5.70 *$ \\
\hline & \multicolumn{4}{|c|}{$\begin{array}{l}\text { Panel B: Distinction by research area, } \\
\text { excluding students using multiple } \\
\text { methods }\end{array}$} & \multicolumn{4}{|c|}{$\begin{array}{l}\text { Panel D: Distinction by future career path, } \\
\text { excluding students using multiple } \\
\text { methods }\end{array}$} \\
\hline Verbal-analytical & 0.22 & 0.14 & 0.26 & 4.50 & 0.14 & 0.20 & 0.20 & 0.86 \\
\hline $\begin{array}{l}\text { Analytical } \\
\text { modelling }\end{array}$ & 0.07 & 0.10 & 0.13 & 1.89 & 0.05 & 0.08 & 0.14 & 3.09 \\
\hline Empirical & 0.28 & 0.39 & 0.23 & $5.39 *$ & 0.24 & 0.33 & 0.33 & 1.17 \\
\hline Case study & 0.00 & 0.06 & 0.00 & $9.61 * * *$ & 0.05 & 0.02 & 0.01 & 1.88 \\
\hline Survey & 0.04 & 0.19 & 0.02 & $19.13 * * *$ & 0.02 & 0.14 & 0.06 & $5.70^{*}$ \\
\hline $\begin{array}{l}\text { Self-created } \\
\text { database }\end{array}$ & 0.06 & 0.02 & 0.00 & $5.37 *$ & 0.00 & 0.03 & 0.05 & 2.25 \\
\hline $\begin{array}{l}\text { External } \\
\text { database }\end{array}$ & 0.03 & 0.02 & 0.15 & $12.66 * * *$ & 0.08 & 0.05 & 0.04 & 1.09 \\
\hline Experiment & 0.00 & 0.01 & 0.02 & 2.30 & 0.00 & 0.01 & 0.01 & 0.69 \\
\hline Other & 0.00 & 0.01 & 0.00 & 2.70 & 0.00 & 0.01 & 0.00 & 1.32 \\
\hline
\end{tabular}

This table shows differences in the methods employed by doctoral students in financial accounting, management accounting and other (related) disciplines (Panels A and B) and differences in the methods employed by doctoral students aiming at a future career in academia, business practice and those who are yet undecided (Panels $\mathrm{C}$ and D). Panels $\mathrm{A}$ and $\mathrm{C}$ report the division for all doctoral students including those using multiple methods, while Panels B and D show the results for those using one single method. $N$ is the number of observations. Statistical significance is determined by the Kruskal-Wallis test and is indicated by $* * *, * *, *$ at the 1,5 and $10 \%$ level, respectively. The $\chi^{2}$ statistic is corrected for ties

all three US mainstream journals and EAR are more frequently consulted by financial accounting researchers, management accounting researchers state to be more familiar with AOS.

With respect to the research method we find that empirical quantitative researchers more strongly reflect the characteristics of the structured model of 
Table 3 Definitions and descriptive statistics

\begin{tabular}{llll}
\hline Variable & Definition & $N$ & Mean \\
\hline Verbal & Verbal-analytical & 293 & 0.48 \\
Model & Analytical modelling & 293 & 0.25 \\
Empquant & Empirical quantitative & 293 & 0.35 \\
Empqual & Empirical qualitative & 293 & 0.11 \\
Statcourse & Attendance of doctoral course in statistics & 293 & 0.40 \\
Econcourse & Attendance of doctoral course in economics & 293 & 0.14 \\
Psychcourse & Attendance of doctoral course in psychology & 293 & 0.08 \\
Confabroad & Conference attendance abroad & 293 & 0.53 \\
Stayabroad & Research stay abroad & 293 & 0.19 \\
Paperbased & Paper-based dissertation & 293 & 0.20 \\
AwareJQ & Awareness of the VHB JOURQUAL ranking & 293 & 0.75 \\
\hline
\end{tabular}

doctoral education: According to their statements in the survey they more often attend courses in statistics, write paper-based dissertations, and they are more likely to be aware of the JOURQUAL ranking. That they have to a certain extent absorbed international trends is also visible in their higher familiarity with US journals (as well as EAR and CPA) and their higher rates of participation in international conferences.

Doctoral students using empirical qualitative approaches differ in a few but important aspects from the rest of the sample. In particular, their international activities in terms of conferences and research stays are more pronounced, and they state to be more familiar with AOS and CPA.

Compared to the rest of our sample, doctoral students applying verbal-analytical reasoning seem to be more nationally oriented as they less often attend international conferences. They are less likely to write a paper-based dissertation and to be aware of the JOURQUAL ranking. They say that they attend fewer courses in statistics, and they are more familiar with the German-speaking journals than other doctoral students.

Doctoral students using analytical modelling only differ in minor points from the rest of the sample: They more often attend courses in economics and less often in statistics than doctoral students employing other methods. With regard to journal familiarity, these doctoral students state to be less familiar with almost all international accounting journals.

In addition to the univariate analyses in Table 6 we also conducted principal component analyses (untabulated) combining one of the four methods with the factors reflecting the institutional setting, respectively. ${ }^{25}$ If we focus on the components for which the respective method has a factor loading of at least 0.5 , we find that empirical-quantitative method choice is associated with courses in statistics, conferences abroad, awareness of the JOURQUAL ranking and (to a

\footnotetext{
${ }^{25}$ We used varimax rotation to obtain a relatively simple structure which allows for interpretation (e.g. Bortz 2004).
} 


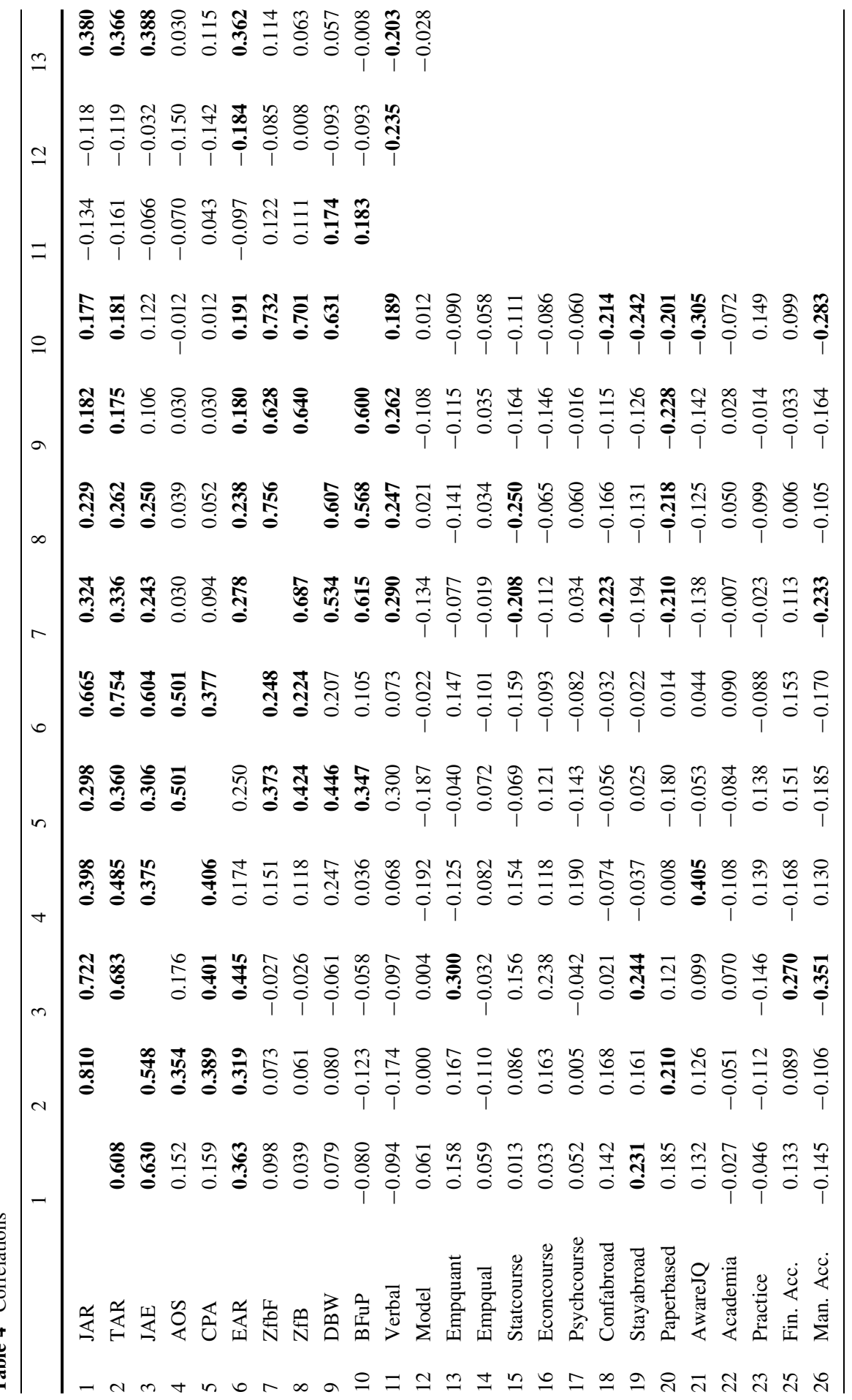




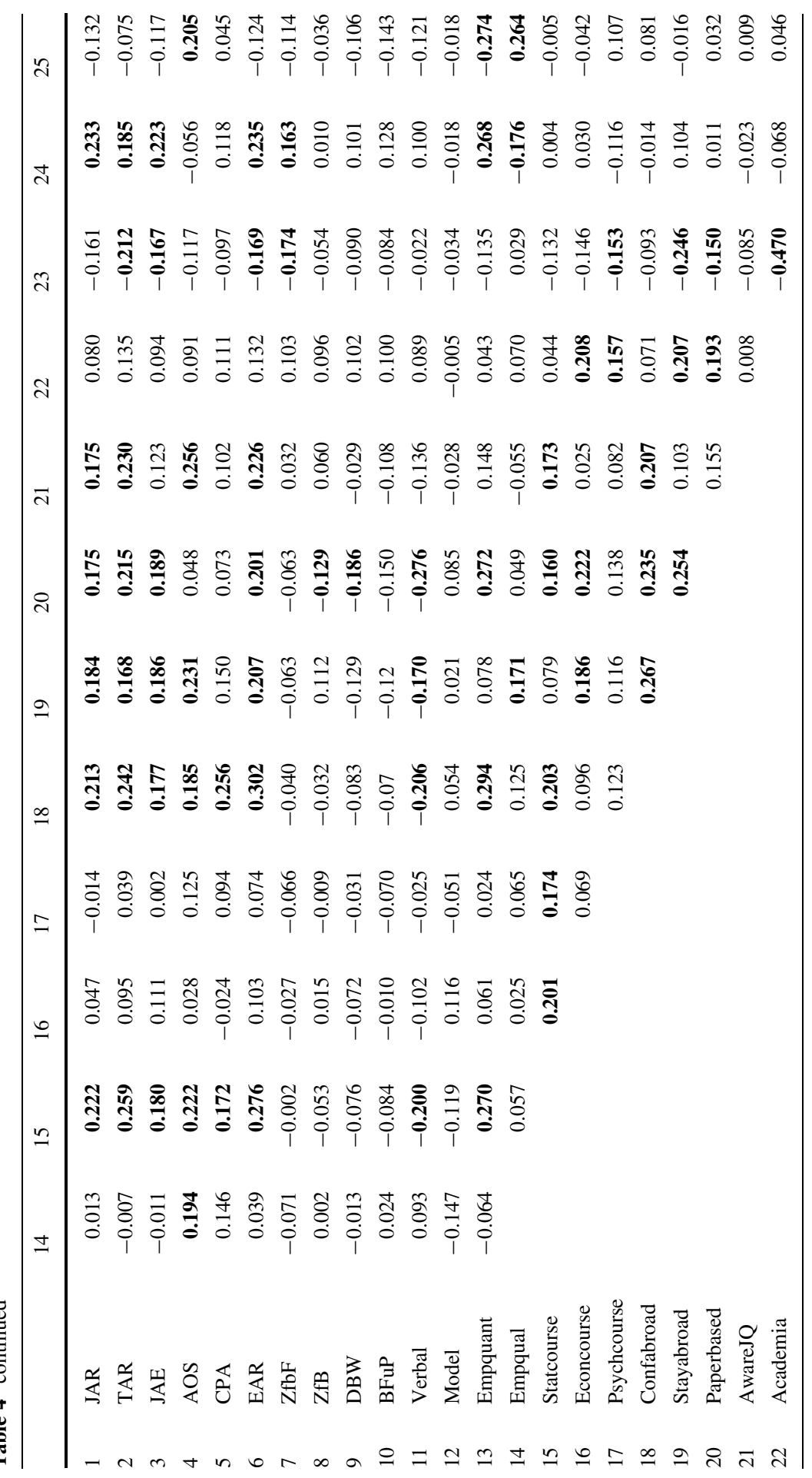




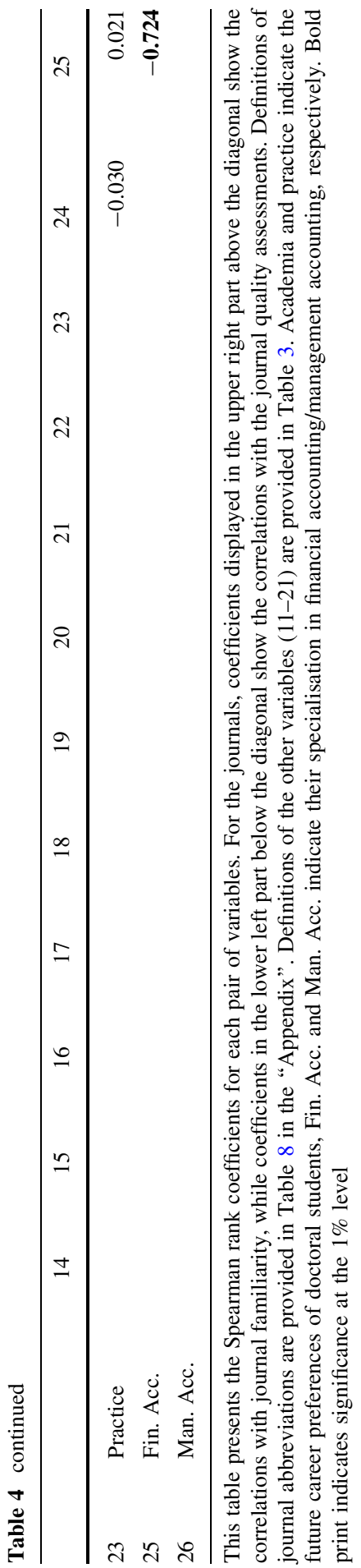


Table 5 Journal familiarity

\begin{tabular}{|c|c|c|c|c|c|c|c|c|}
\hline & $\begin{array}{l}\text { Fin. Acc. } \\
\text { Mean }\end{array}$ & $\begin{array}{l}\text { Man. Acc. } \\
\text { Mean }\end{array}$ & $\begin{array}{l}\text { Other } \\
\text { Mean }\end{array}$ & $\chi^{2}$ & $\begin{array}{l}\text { Verbal } \\
\text { Mean }\end{array}$ & $\begin{array}{l}\text { Model } \\
\text { Mean }\end{array}$ & $\begin{array}{l}\text { Empquant } \\
\text { Mean }\end{array}$ & $\begin{array}{l}\text { Empqual } \\
\text { Mean }\end{array}$ \\
\hline & \multicolumn{4}{|c|}{ Panel A: Distinction by research area } & \multicolumn{4}{|c|}{ Panel B: Distinction by research method } \\
\hline JAR & 5.11 & 4.21 & 3.65 & $14.34 * * *$ & $4.21 * *$ & $4.10 *$ & $5.48 * * *$ & 4.57 \\
\hline JAE & 4.81 & 4.00 & 3.41 & $13.69 * * *$ & 4.11 & 4.13 & $5.29 * * *$ & 4.25 \\
\hline TAR & 5.24 & 4.50 & 3.71 & $10.82 * * *$ & $4.31 * * *$ & $4.25^{*}$ & $5.66^{* * * *}$ & 4.68 \\
\hline AOS & 3.02 & 3.74 & 2.15 & $15.76^{* * *} *$ & 3.03 & $2.67 * *$ & 3.28 & $4.57 * * *$ \\
\hline CPA & 2.87 & 2.66 & 1.65 & $13.70 * * *$ & 2.72 & $2.12 * *$ & $2.88 *$ & $3.29 * *$ \\
\hline EAR & 5.20 & 4.32 & 3.62 & $15.13 * * *$ & 4.40 & $3.85 * * *$ & $5.48 * * *$ & 4.89 \\
\hline $\mathrm{ZfbF}$ & 6.01 & 5.23 & 5.29 & $6.53 * *$ & $5.90 * * *$ & $5.22 *$ & 5.65 & 5.29 \\
\hline ZfB & 5.72 & 5.42 & 5.68 & 0.34 & $5.88 * * *$ & 5.57 & 5.66 & 5.54 \\
\hline DBW & 5.51 & 5.00 & 5.26 & 3.31 & $5.61 * * *$ & 4.97 & 5.35 & 5.18 \\
\hline BFuP & 5.41 & 4.69 & 5.18 & $5.75^{*}$ & $5.48 * * *$ & $4.70 *$ & 4.99 & 5.14 \\
\hline
\end{tabular}

This table shows differences in doctoral students' familiarity with different accounting journals. Panel A reports the differences with regard to the specialisation of doctoral students in financial accounting, management accounting and other (related) disciplines. Significance of the differences is determined by the Kruskal-Wallis test. The $\chi^{2}$ statistic is corrected for ties. Panel B reports the differences by method, including doctoral students using multiple methods. The $t$ test is used for each method to determine the significance of differences compared to the respective rest of the sample. Statistical significance is indicated by $* * *, * *, *$ at the 1,5 and $10 \%$ level, respectively. Journal abbreviations are explained in Table 8 in the "Appendix"

Table 6 Institutional factors

\begin{tabular}{|c|c|c|c|c|c|c|c|c|}
\hline & $\begin{array}{l}\text { Fin. Acc. } \\
\text { Mean }\end{array}$ & $\begin{array}{l}\text { Man. Acc. } \\
\text { Mean }\end{array}$ & $\begin{array}{l}\text { Other } \\
\text { Mean }\end{array}$ & $\chi^{2}$ & $\begin{array}{l}\text { Verbal } \\
\text { Mean }\end{array}$ & $\begin{array}{l}\text { Model } \\
\text { Mean }\end{array}$ & $\begin{array}{l}\text { Empquant } \\
\text { Mean }\end{array}$ & $\begin{array}{l}\text { Empqual } \\
\text { Mean }\end{array}$ \\
\hline & \multicolumn{4}{|c|}{ Panel A: Distinction by research area } & \multicolumn{4}{|c|}{ Panel B: Distinction by research method } \\
\hline Statcourse & 0.40 & 0.40 & 0.40 & 0.01 & $0.30 * * *$ & $0.30 *$ & $0.58 * * *$ & 0.48 \\
\hline Econcourse & 0.15 & 0.12 & 0.15 & 0.50 & $0.10^{*}$ & $0.21 *$ & 0.17 & 0.16 \\
\hline Psychcourse & 0.04 & 0.11 & 0.09 & 4.17 & 0.07 & 0.05 & 0.09 & 0.13 \\
\hline Confabroad & 0.52 & 0.58 & 0.43 & 3.15 & $0.42 * * *$ & 0.58 & $0.73 * * *$ & $0.71 * *$ \\
\hline Stayabroad & 0.24 & 0.18 & 0.09 & $5.28 *$ & $0.12 * * *$ & 0.21 & 0.23 & $0.39 * * *$ \\
\hline Paperbased & 0.21 & 0.22 & 0.15 & 0.99 & $0.09 * * *$ & 0.26 & $0.35 * * *$ & 0.26 \\
\hline AwareJQ & 0.74 & 0.75 & 0.77 & 0.19 & $0.69 * *$ & 0.73 & $0.83^{* *}$ & 0.68 \\
\hline
\end{tabular}

This table shows differences in institutional factors of doctoral education. Panel A reports the differences with regard to the specialisation of doctoral students in financial accounting, management accounting and other (related) disciplines. Significance of the differences is determined by the Kruskal-Wallis test. The $\chi^{2}$ statistic is corrected for ties. Panel B reports the differences by method, including doctoral students using multiple methods. The Pearson $\chi^{2}$-test is used for each method to determine the significance of differences compared to the respective rest of the sample. Statistical significance is indicated by $* * *, * *$, * at the 1, 5 and 10\% level, respectively. Definitions of all variables are provided in Table 3 
lesser extent) paper-based dissertations. ${ }^{26}$ Qualitative empirical research is related to conferences and research stays abroad, while analytical modelling is negatively associated with courses in statistics and psychology as well as awareness of the JOURQUAL ranking but positively with courses in economics. Verbal-analytical research is negatively related to research stays and conferences abroad, paper-based dissertations and awareness of the ranking. While it is to note that these results have to be treated cautiously as the stability of the findings is sensitive to including further variables, the results for the empirical quantitative and qualitative as well as the verbal-analytical methods corroborate our findings from the univariate analysis in Table 6.

\subsection{Limitations}

Our insights are restricted by a number of limitations that are rooted in the nature of the research approach adopted. First, we lack information on characteristics of the degree granting institution and the supervisor of the doctoral students in our sample because we guaranteed anonymity to every participant in our survey in order to ensure a high response rate. Hence, it is not possible to draw inferences, for example, with regard to the particularities of elite schools vs. non-elite schools (Schwartz et al. 2005) or schools with a more formal program of doctoral education vs. others. Moreover, we also cannot relate doctoral students' approaches to their supervisors' degree of internationalisation and publication orientation and the methods employed in her/his own research. While these issues might to some extent be captured in variables such as paper-based dissertations or doctoral students' participation in international conferences, our survey data do not permit us to distinguish clearly whether the research orientation of the doctoral student is mainly triggered by him- or herself, the supervisor's research orientation, or the effects of the institutional setting.

Second, while we are able to provide certain indications of relations between institutional variables and the research methods adopted by doctoral students, we cannot establish robust multivariate statistical findings that allow for the identification of certain ideal types in our dataset. In our view, this can at least partly be explained by the fact that the time of our survey reflects a period of transition where different forms and degrees of course programs, internationalisation and publication orientation were established at different places.

Third, our survey is a one-shot analysis with a focus on only one geographical area and discipline. Thus, our results can only claim validity with regard to the time of our survey, the German-speaking countries and the discipline of accounting. In particular, our data do not allow us to draw comparisons between disciplines or countries and to depict long-term changes in the institutional setting and the research methods adopted. However, we note that this setup enables us to hold many other factors beyond academia as well as the group of respondents constant (e.g. Backhaus et al. 2010).

\footnotetext{
${ }^{26}$ We focus on those factors in the same component that at least reach a level of 0.2 . While we acknowledge that these factor loadings are below the recommendations of some statistical textbooks (e.g. Bortz 2004; Backhaus et al. 2010), other literature suggests to use factor loadings above a level of 0.15 for explorative factor analyses (e.g. Ford et al. 1986).
} 
Fourth, surveys are subject to several possible biases. For example, common method biases could have distorted the results (Podsakoff et al. 2003). While we have addressed the major common method biases relevant to our research, which are the common scale bias and the consistency motif bias, by randomising the order of the questions (also cf. Hull and Wright 1990) and, for example, placing questions about research methods and journal rankings at different places in the questionnaire, some additional limitations might nonetheless exist. Like other perception studies, we also suffer from not knowing the context from which respondents acted as judges when they evaluated the journals (Milne 2002; Weber and Stevenson 1981). We tested for possible non-response bias in that we compared those participants who took part after the final call $(n=36)$ with the rest of our sample with regard to the assessments of familiarity with journals. We did not detect any significant differences with regard to either group.

Finally, as we used the survey method, we also cannot claim to have studied in detail the processes which influence doctoral students' choice of research methods. Further research might observe research practices in more detail and provide more nuanced views on the ramifications displayed by the changes in the setting of doctoral education. In a similar vein, our study centres exclusively on a set of accounting journals and research methods, but does not consider the theories employed by doctoral students.

\section{Discussion}

In this paper, we analyse research diversity among doctoral students in the Germanspeaking area in a period of transition. With respect to the first research question on doctoral students' familiarity with and quality assessments of accounting journals, we find that the traditionally predominant role played by national outlets is still present at the time of our survey. There is also considerable awareness of international outlets, in particular those with a US focus and EAR, while critical-interpretive perspectives are less known by doctoral students in the German-speaking area. To some extent, this result can be contrasted with the study by Schwartz et al. (2005). While CPA is unknown to most German-speaking and US doctoral students alike, familiarity with top US journals and with AOS is less pronounced in the German-speaking setting than it is in the US. In line with the observation by Pelger and Grottke (2015) we can conclude that the international orientation by $\mathrm{PhD}$ students largely relates to positivistic journal discourses and rarely to critical-interpretive journals. However, we also find that doctoral students are familiar with EAR, a journal which, at least in 2009, still relatively regularly published research from different paradigms (Carmona et al. 1999; Locke and Lowe 2008). ${ }^{27}$

\footnotetext{
27 Awareness of EAR might be related to the EAA conferences, where participants from the Germanspeaking area have formed the largest group in recent years (Schäffer 2013) and where a substantial number of doctoral students present their current research. Fülbier and Weller (2011) observe a notable rise in the number of international publications by German-speaking financial accounting scholars since the introduction of EAR at the beginning of the 1990s (in line with EAR's policy of integrating paradigms from different European traditions, cf. Carmona et al. 1999; Carmona 2002). This might also explain relatively high levels of familiarity with this journal among doctoral students.
} 
In this regard, our correlation analysis reveals that familiarity with EAR played a bridging role between positivistic and critical-interpretive paradigms at that point in time. ${ }^{28}$ The role of EAR in building bridges across different paradigms is important because it exposes doctoral students to different discourses and thus might foster diversity in their own research. This finding highlights how important it is to keep association journals, such as EAR, open to multiple paradigms through open editorial policies (e.g. Oler et al. 2016; Malsch and Salterio 2016) and the choice of editorial board members from different paradigms (Chapman 2012).

With respect to the quality dimension, we find that international journals were more favourably assessed than German journals. An explanation might be the existence of a reverse home bias in that local research is downgraded just because it is German. The latter point can be related to the results of a survey by Brinn et al. (1996) according to which UK academics tend to estimate the quality of their homecountry journals to be worse than the quality of the US journals. This result is in particular noteworthy, as a clear majority in the British study even indicated that they do not envisage to make any effort to publish in US journals (Brinn et al. 1996, 2001).

Another reason for downgrading local journals might be that doctoral students' quality judgements are influenced by the quasi-authoritative quality assessments of JOURQUAL (Kieser 2012). Along this line, in additional analyses we find that if the journal ranking is known, doctoral students consistently downgrade the quality they assign to the German journals (see Table 7). In particular, in Panel A of Table 7 only few differences between the international accounting journals and the German journals are significant which suggests that those doctoral students not aware of JOURQUAL $(n=68)$ do not perceive major differences in the quality between international and German journals. ${ }^{29}$

Correlations of journal quality assessments might be interpreted as demonstrating how the traditional German journals, on the one hand, and the US mainstream journals, on the other hand, are each perceived to offer a discourse of a rather uniform type of quality, while EAR, AOS and CPA are too diverse to fall into one of these two discourses. Thus, our findings corroborate that doctoral students perceive the homogenous (monolithic) character of the three positivist US journals that was also noted by Williams et al. (2006) and that contrasts markedly with the low consensus social science research that can be found in critical-interpretive outlets (Lee and Williams 1999). This interpretation is also in line with the observations of Locke and Lowe (2008) who show that the quality assessments of UK and Australasian academics differ with respect to AOS and CPA, while they are rather similar for the three US journals. Furthermore, doctoral students also seem to

\footnotetext{
28 This result can be distinguished from the citation study of Wakefield (2008) where AOS was playing the role of bridging different paradigms. This difference may be attributable to the scant dissemination of AOS among German-speaking doctoral students. However, note that in our study AOS plays a bridging role between EAR and CPA.

29 Additional analyses (Wilcoxon ranksum tests, untabulated) of how the differences in quality assessments of the four international journals on the one hand and the German journals on the other hand differ with respect to the awareness of JOURQUAL show significant differences (at least) at the $10 \%$ level for all combinations except for DBW and TAR/JAE/EAR and ZfbF and JAE/EAR.
} 
Table 7 Differences between quality assessments of journals

\begin{tabular}{|c|c|c|c|c|c|c|c|c|}
\hline & & 1 & 2 & 3 & 4 & 5 & 6 & 7 \\
\hline \multicolumn{9}{|c|}{ Panel A: Doctoral students not aware of JOURQUAL } \\
\hline 1 & JAR & & & & & & & \\
\hline 2 & TAR & 0.227 & & & & & & \\
\hline 3 & JAE & -0.100 & -0.143 & & & & & \\
\hline 4 & EAR & -0.471 & -0.318 & -0.333 & & & & \\
\hline 5 & $\mathrm{ZfbF}$ & -0.227 & -0.222 & -0.273 & 0.174 & & & \\
\hline 6 & $\mathrm{ZfB}$ & -0.375 & -0.607 & -0.333 & -0.174 & -0.260 & & \\
\hline 7 & DBW & -1.000 & -1.185 & -0.913 & -0.783 & -0.745 & -0.511 & \\
\hline 8 & $\mathrm{BFuP}$ & -0.333 & -0.423 & -0.364 & -0.400 & -0.250 & -0.022 & 0.455 \\
\hline \multicolumn{9}{|c|}{ Panel B: Doctoral students aware of JOURQUAL } \\
\hline 1 & JAR & & & & & & & \\
\hline 2 & TAR & -0.172 & & & & & & \\
\hline 3 & JAE & $-\mathbf{0 . 3 3 7}$ & -0.147 & & & & & \\
\hline 4 & EAR & -0.699 & -0.496 & -0.300 & & & & \\
\hline 5 & $\mathrm{ZfbF}$ & -1.000 & -0.876 & -0.755 & -0.413 & & & \\
\hline 6 & $\mathrm{ZfB}$ & -1.331 & -1.228 & -1.162 & -0.748 & -0.290 & & \\
\hline 7 & DBW & -1.862 & -1.724 & -1.610 & -1.282 & -0.837 & -0.541 & \\
\hline 8 & BFuP & -1.964 & -1.798 & -1.716 & -1.350 & -0.854 & -0.549 & -0.047 \\
\hline
\end{tabular}

This table presents the mean differences of the journal quality assessments for those doctoral students not aware of the JOURQUAL ranking (Panel A) and those doctoral students aware of JOURQUAL (Panel B). As the number of those students in Panel A who felt able to judge the quality of AOS and CPA is relatively low (10 of 68 students), results for these journals are not shown. Significance of the differences is tested by using a paired ttest (with two-tailed $p$ values). Bold print indicates significance at the $1 \%$ level

perceive the traditional German business economics journals as representing a rather monolithic discourse. However, this perception might have changed in the years after our survey was conducted as these journals adopted different strategies. While ZfB followed trends of internationalisation and completely switched to English in 2013, even changing its title to Journal of Business Economics, DBW ${ }^{30}$ and BFuP remain primarily German-language publications. Already since the year 2000, several issues of ZfbF have been published each year in English under the title of Schmalenbach Business Review which was thus the first English language outlet in the German-speaking area.

With respect to the second research question, on the extent of diversity in the research methods adopted by accounting doctoral students in their dissertations, our results reveal that, overall, doctoral students stated that they take various different approaches-empirical, analytical modelling and verbal-analytical-to their research. Moreover, they frequently declare that they employ multiple approaches in their doctoral dissertations, which suggests a certain awareness of the existence of

\footnotetext{
${ }^{30}$ Recently, the publisher of DBW decided to stop the operation of the journal at the end of 2016. Cf. http://www.dbwnet.de/index.php?mod=news_all\&newsid=19.
} 
other approaches. We show that differences exist, particularly over what specific empirical approach is adopted, depending on whether the doctoral student is specialising in financial or management accounting: while management accounting researchers more often use surveys or case studies, empirical research in financial accounting mostly takes an archival approach (using databases). The former finding is in line with results on journal publications in the literature (Binder and Schäffer 2005; Wagenhofer 2006) arguing that data availability might be a major reason for the relative scarcity of archival research by management accounting academics. The focus on surveys and case studies, however, is in contrast to the US where empirical-archival approaches are dominant in management accounting (Merchant 2010). For financial accounting our finding is broadly consistent with the publication analysis produced by Perrey et al. (2010). However, doctoral students in financial accounting seem to use survey data more often than the articles published in academic journals. This might suggest that difficulties are encountered in publishing survey research in German academic journals. That our group of "other" specialisations is less prone to empirical work is something which may be attributable to the large number of doctoral students specialising in taxation in this group, a subject which at least traditionally is less geared to empirical approaches, owing to the lack of data (e.g. Shackleford and Shevlin 2001). Summing up, the diversity in terms of method that we find in our sample from 2009 suggests that there was at least at that time no single focus on the adoption of US positivistic approaches.

With respect to the third research question on the relationship between accounting journals, research methods and the institutional setting, we find that different characteristics of the institutional environment of doctoral education are associated with the adoption of different research methods. A possible interpretation of our results suggests that in particular empirical quantitative research seems to resonate with institutional factors of the new setting of doctoral education. While empirical qualitative researchers also show high levels of international activity, verbal-analytical researchers have little relations to any of the characteristics of the new model of doctoral education. Thus, the forging of stronger links to the international accounting community and the establishment of structured doctoral programs at that time seemed to have coincided, at least to some extent, with quantitative (and partly qualitative) methods being adopted.

\section{Potential implications for accounting academia in the German- speaking countries}

In the light of the recent changes that have taken place in doctoral education, our results might suggest that the new way in which doctoral education is now being configured at several German-speaking business schools, with its emphasis on structured course programs, internationalisation and publications in (international) journals, is likely to promote empirical quantitative (and, to a lesser extent, empirical qualitative) research but is neglecting traditional verbal-analytical research. 
Taking into account the literature concerned with looming homogeneity in accounting research (e.g. Hopwood 2007, 2008), this might lead to a state of affairs similar to that in the US where the approach to doctoral education is not very diverse across different schools (e.g. Granof and Zeff 2008) and doctoral students are socialised with very clear guidance on what constitutes good and appropriate research (e.g. Panozzo 1997; Beyer et al. 2010). On the one hand, such a homogenous institutional setting of doctoral education might trigger efficiency gains and lead to better-trained doctoral students in the methods offered in $\mathrm{PhD}$ programs. On the other hand, it might have an effect on the broader setting of academia as conservative structures that generate homogeneity (Hopwood 2007) are, according to literature from the US, accompanied by a lack of innovation (Kaplan 2011; Waymire 2012) and a stifling of open discourse (Williams and Rodgers 1995; Tuttle and Dillard 2007). Along this line, we find that prospective academics among our surveyed accounting doctoral students tend to rely more on commercial databases than other doctoral students. While one reason for this result might be that the use of commercial databases allows for the more efficient production of research output compared to other, possibly more time-consuming forms of data collection, it also shows that doctoral students aiming at academia tend to employ the method prevailing in the US.

However, an important finding from our empirical evidence for local accounting communities in this regard might be that the institutional change must not necessarily end in homogeneity. The fact that we can observe German-speaking doctoral students choosing qualitative methods to be active at an international level ${ }^{31}$ might indicate the availability of different routes for the future development of academia. While our study indicates that some doctoral students, primarily in management accounting, might be following this route, which might even resonate well with the new performance-oriented academic culture (Messner 2015), the absolute number of doctoral students choosing such a method is, in fact, comparatively small. Moreover, familiarity with AOS and CPA is not widespread among doctoral students. The finding that despite an ever increasing focus on journal rankings, qualitative research has not penetrated doctoral students in accounting affiliated with schools in the German-speaking countries on a broader scale so far might well be due to the traditional lack of critical-interpretive perspectives in German-speaking accounting academia (e.g. Becker and Messner 2005; Power 2004). Whether this route to qualitative and critical-interpretive research is perceived by doctoral students as an attractive option for their own research, might, therefore, crucially depend on how this approach is embedded in doctoral education. Introducing courses on qualitative accounting research, as it was first done by the accounting section of the VHB in 2015 (WK RECH 2015), might be a promising way to maintain and foster diversity in this regard.

On the other hand, the viability of the traditional normative approach may in future be called into question. Indeed, German-speaking researchers employing

\footnotetext{
31 International events which might serve as inputs for those doctoral students carrying out qualitative research are, for example, the Interdisciplinary Perspectives on Accounting (IPA) conference, events organized by the European Institute for Advanced Studies in Management (EIASM) and sessions at the annual meeting of the European Accounting Association.
} 
verbal-analytical research approaches have not managed, or have arguably not even seriously attempted, to promote their normative research approach in the international arena to complement positivistic and/or critical-interpretive research. This might well be attributable to the absence of international networks, something that has its roots in the international isolation that was characteristic for German accounting academics until the beginning of this century (Küpper and Mattessich 2005; Wagenhofer 2006). The national orientation is notable as there has been room for normative research on the international level: for example, EAR and other international journals, such as Abacus or Accounting and Business Research, have published normative papers (Pelger and Grottke 2015). We conclude that if normative research is to be kept as a sustainable alternative in a revised institutional setting, this tradition would need to be incorporated into the structured model of doctoral education by, for example, establishing courses on accounting theory and to be promoted more broadly at an international level. Given the still considerable number of accounting researchers carrying out normative accounting research in the German-speaking area and the fact that this line of research also exists in other parts of the world (e.g. Rutherford 2010 for the UK; Miller and Bahnson 2010 for the US) it might be a fruitful avenue for those researchers to open up more to the international community. Benefits might also arise from combining the German tradition of practically relevant normative accounting research with the theoretical conceptions and qualitative empirical approaches of interpretive or critical research.

Finally, the empirical results presented in this paper open up avenues for future research with respect to similar changes towards internationalisation and structured doctoral education in other countries, particularly in the European Union in the wake of the Bologna process (Djelic 2008), which, however, have different (local) points of departure. In some countries, this development seems to have been concluded a while ago (e.g. France), while elsewhere reforms in this direction have still not been started (e.g. Romania) (for both examples cf. Urdari et al. 2015). In particular, it would be interesting to learn more about the specific (hybrid) forms of doctoral education existing in European countries and their link to the research diversity among doctoral students.

Acknowledgements We would like to thank Michael Lorenz for his valuable assistance in constructing the survey and Christian Drefahl and Johanna Riedner for their help in collecting the contact details of doctoral students. We also thank Neil Jackson for his excellent assistance in language editing. Furthermore, we are grateful to all participants in the pre-tests and the final survey. We also thank Albrecht Becker, Dominic Detzen, Rolf Uwe Fülbier (VHB discussant), Sebastian Hoffmann, Chris Humphrey, Lukas Löhlein, Bernard Needles, Ulrich Schäfer and participants in doctoral colloquia at the University of Cologne and the University of Passau, participants in the EAA Conference in Ljubljana 2012, in the BAFA Annual Meeting 2012 in Brighton, the joint VHB/IAAER conference in Eschborn 2013 and the VHB Pfingsttagung 2015 in Vienna for helpful comments. Of course, all remaining errors remain the sole responsibility of the authors. Christoph Pelger gratefully acknowledges the financial support provided by the German National Academic Foundation.

Open Access This article is distributed under the terms of the Creative Commons Attribution 4.0 International License (http://creativecommons.org/licenses/by/4.0/), which permits unrestricted use, distribution, and reproduction in any medium, provided you give appropriate credit to the original author(s) and the source, provide a link to the Creative Commons license, and indicate if changes were made. 


\section{Appendix}

Table 8 Journal abbreviations and JOURQUAL ranking positions

\begin{tabular}{lll}
\hline Abbreviation & Journal title & JOURQUAL ranking \\
\hline AOS & Accounting, Organizations and Society & A \\
BFuP & Betriebswirtschaftliche Forschung und Praxis & D \\
CPA & Critical Perspectives on Accounting & B \\
DBW & Die Betriebswirtschaft & C \\
EAR & European Accounting Review & B \\
JAE & Journal of Accounting \& Economics & A \\
JAR & Journal of Accounting Research & A \\
TAR & The Accounting Review & A \\
ZfB & Zeitschrift für Betriebswirtschaft & B \\
ZfbF & Zeitschrift für betriebswirtschaftliche Forschung & B
\end{tabular}

This table shows all journal abbreviations for the journals used in our study and the respective positions in the JOURQUAL2 (2008) ranking. Categories of JOURQUAL range from A + as the best category down to $\mathrm{E}$ as the worst category

\section{References}

Ahrens, Thomas, Albrecht Becker, John Burns, Christopher S. Chapman, Markus Granlund, Michael Habersam, Allan Hansen, Rahib Khalifa, Teemu Malmi, Andrea Mennicken, Anette Mikes, Fabrizio Panozzo, Martin Piber, Paolo Quattrone, and Tobias Scheytt. 2008. The future of interpretive accounting research: A polyphonic debate. Critical Perspectives on Accounting 19: 840-866.

Alexander, David, and Eva Eberhartinger. 2009. The true and fair view in the European Union. European Accounting Review 18: 571-594.

Backhaus, Klaus, Bernd Erichson, Wulff Plinke, and Rolf Weiber. 2010. Multivariate Analysemethoden, 13th ed. Berlin: Springer.

Ballas, Apostolos, and Vasilis Theoharakis. 2003. Exploring diversity in accounting through faculty journal perceptions. Contemporary Accounting Research 20: 619-644.

Beattie, Vivien, and Sarah Jane Smith. 2012. Today's PhD students-is there a future generation of account-ing academics or are they a dying breed? A UK perspective. Edinburgh: The Institute of Chartered Accountants of Scotland (ICAS).

Becker, Albrecht, and Martin Messner. 2005. After the scandals: A German-Speaking perspective on management accounting research and education. European Accounting Review 14: 417-427.

Beyer, Brooke, Don Hermann, Gary K. Meek, and Eric T. Rapley. 2010. What it means to be an accounting professor: A concise career guide for doctoral students in accounting. Issues in Accounting Education 25: 227-244.

Binder, Christoph, and Utz Schäffer. 2005. Die Entwicklung des Controllings von 1970 bis 2003 im Spiegel der Publikationen in deutschsprachigen Zeitschriften. Die Betriebswirtschaft 65: 603-626.

Bonner, Sarah E., James W. Hesford, Wim A. Van der Stede, and S. Mark Young. 2006. The most influential journals in academic accounting. Accounting, Organizations and Society 31: 663-685.

Bortz, Jürgen. 2004. Statistik für Human- und Sozialwissenschaftler, 6th ed. Berlin: Springer.

Brink, Alisa G., Robson Glasscock, and Benson Wier. 2012. The current state of accounting Ph. D. programs in the United States. Issues in Accounting Education 27: 917-942.

Brinn, Tony, Michael John Jones, and Maurice Pendlebury. 1996. UK accountants' perceptions of research journal quality. Accounting and Business Research 26: 265-278.

Brinn, Tony, Michael John Jones, and Maurice Pendlebury. 2001. Why do UK accounting and finance academics not publish in top US journals. British Accounting Review 33: 223-232. 
Carmona, Salvador, Isabel Gutiérrez, and Macario Cámara. 1999. A profile of European accounting research: Evidence from leading research journals. European Accounting Review 8: 463-480.

Carmona, Salvador. 2002. History matters: Lessons from twenty-five years of the European Accounting Association. European Accounting Review 11: 9-32.

Chan, Kam C., Gim S. Seow, and Kinsun Tam. 2009. Ranking accounting journals using dissertation citation analysis: A research note. Accounting, Organizations and Society 34: 875-885.

Chapman, Christopher S. 2012. Framing the issue of research quality in a context of research diversity. Accounting Horizons 26: 821-831.

Chua, Wai-Fong. 1986. Radical developments in accounting thought. The Accounting Review 61: 601-632.

Cook, Wade D., Tal Ravivi, and Alan J. Richardson. 2010. Aggregating incomplete lists of journal rankings: An application to academic accounting journals. Accounting Perspectives 9: 217-235.

DFG. 2012. Förderatlas 2012: Kennzahlen zur öffentlich finanzierten Forschung in Deutschland. Weinheim: Wiley.

Djelic, Marie-Laure. 2008. PhD education - challenges and opportunities for Europeanization. In European universities in transition, ed. Carmelo Mazza, Paolo Quattrone, and Angelo Riccaboni, 49-68. Cheltenham: Edward Elgar.

Fogarty, Timothy J., and Gregory A. Jonas. 2010. The hand that rocks the cradle: Disciplinary socialization at the American Accounting Association's Doctoral Consortium. Critical Perspectives on Accounting 21: 303-317.

Ford, Kevin, Robert C. MacCallum, and Marianne Tait. 1986. The application of exploratory factor analysis in applied psychology: A critical review and analysis. Personnel Psychology 36: 291-314.

Fülbier, Rolf Uwe, and Manuel Weller. 2008. Normative Rechnungslegungsforschung im Abseits? Einige wissenschaftstheoretische Anmerkungen. Journal for General Philosophy of Science 39: 351-382.

Fülbier, Rolf Uwe, and Manuel Weller. 2011. A glance at German financial accounting research between 1950 and 2005: A publication and citation analysis. Schmalenbach Business Review 63: 2-33.

Gendron, Yves. 2008. Constituting the academic performer: The spectre of superficiality and stagnation in academia. European Accounting Review 17: 97-127.

Grochla, Erwin. 1976. Praxeologische Organisationstheorie durch sachliche und methodische Integration. Zeitschrift für betriebswirtschaftliche Forschung 28: 617-637.

Granof, Michael H., and Stephen A. Zeff. 2008. Research on accounting should learn from the past. Chronicle of Higher Education 58: A34.

Grottke, Markus, Christoph Pelger, and Claudia Schmiedeberg. 2013. Firm or faculty? Evidence on characteristics of German-speaking accounting $\mathrm{PhD}$ students and their career preferences. Accounting Education: An International Journal 22: 66-84.

Hopwood, Anthony G. 2007. Whither accounting research. The Accounting Review 82: 1365-1374.

Hopwood, Anthony G. 2008. Changing pressures on the research process: On trying to research in an age when curiosity is not enough. European Accounting Review 17: 87-96.

Howard, Thomas P., and Loren A. Nikolai. 1983. Attitude measurement and perceptions of accounting faculty publication outlets. The Accounting Review 58: 765-776.

Hull, R.P., and G.B. Wright. 1990. Faculty perceptions of journal quality: An update. Accounting Horizons 4: 77-98.

Kaplan, Robert S. 2011. Accounting scholarship that advances professional knowledge and practice. The Accounting Review 86: 367-383.

Khalifa, Rihab, and Paolo Quattrone. 2008. The governance of accounting academy: Issues for a debate. European Accounting Review 17: 65-86.

Kieser, Alfred. 2012. JOURQUAL - der Gebrauch, nicht der Missbrauch, ist das Problem. Die Betriebswirtschaft 72: 93-110.

Krejcie, Robert V., and Darayle W. Morgan. 1970. Determining sample size for research activities. Educational and Psychological Measurement 30: 607-610.

Kuhn, Thomas. 1996. Die Struktur wissenschaftlicher Revolutionen. Frankfurt: Suhrkamp.

Kuhner, Christoph. 1997. Maintaining economic stability as a motive for statutory accounting requirement. European Accounting Review 6: 733-754.

Küpper, Hans-Ulrich, and Richard Mattessich. 2005. Twentieth century accounting research in the German language area. Accounting, Business and Financial History 15: 345-410.

Lee, Tom A. 2004. Accounting and auditing research in the United States. In The real life guide to accounting research, eds. Chris Humphrey, and Bill Lee, 57-71. Amsterdam: Elsevier. 
Lee, Tom A., and Paul F. Williams. 1999. Accounting from the inside: Legitimizing the accounting academic elite. Critical Perspectives on Accounting 10: 867-895.

Locke, Joanne, and Alan Lowe. 2008. Evidence and implications of multiple paradigms in accounting knowledge production. European Accounting Review 17: 161-191.

Lohmann, Christian. 2012. Die Entwicklung der Publikationstätigkeit in der Zeitschrift für Betriebswirtschaft. Zeitschrift für Betriebswirtschaft 82: 303-325.

Lowe, Alan, and Joanne Locke. 2005. Perceptions of journal quality and research paradigm: Results of a web-based survey of British accounting academics. Accounting, Organizations and Society 30: 81-98.

Lukka, Kari, and Eero Kasaanen. 1996. Is accounting a global or a local discipline? Evidence from major research journals. Accounting, Organizations and Society 21: 755-773.

Lukka, Kari. 2010. The roles and effects of paradigms in accounting research. Management Accounting Research 21: 110-115.

Macintosh, Norman. 2004. A ghostly CAR ride. Critical Perspectives on Accounting 15: 675-695.

Malsch, Bertrand, and Steven E. Salterio. 2016. "Doing good field research": Assessing the quality of audit field research. Auditing: A Journal of Practice and Theory 35: 1-22.

Merchant, Kenneth A. 2010. Paradigms in accounting research: A view from North America. Management Accounting Research 21: 116-120.

Messner, Martin. 2015. Research orientation without regrets. Critical Perspectives on Accounting 26: 76-83.

Messner, Martin, Albrecht Becker, Utz Schäffer, and Christoph Binder. 2008. Legitimacy and identity in Germanic management accounting research. European Accounting Review 17: 129-159.

Miller, Paul B.W., and Paul R. Bahnson. 2010. Continuing the normative dialog: Illuminating the Asset/ Liability theory. Accounting Horizons 24: 419-440.

Milne, Markus J. 2002. The construction of journal quality: No engagement detected. Accounting Forum 26: 72-86.

Oler, Derek K., Mitchell J. Oler, and Christopher J. Skousen. 2010. Characterizing accounting research. Accounting Horizons 24: 635-670.

Oler, Derek K., Mitchell J. Oler, Christopher J. Skousen, and Jayson Talakai. 2016. Has concentration in the top six accounting journals changed over time? Accounting Horizons 30: 63-78.

Ordelheide, Dieter. 1993. True and fair view: A European and a German perspective. European Accounting Review 2: 81-90.

Panozzo, Fabrizio. 1997. The making of the good academic accountant. Accounting, Organizations and Society 22: 447-480.

Pelger, Christoph, and Markus Grottke. 2015. What about the future of the academy? Some remarks on the looming colonisation of doctoral education. Critical Perspectives on Accounting 26: 117-129.

Pelger, Christoph, and Markus Grottke. 2016. Kein schöner Land in dieser Zeit? Promotionsbedingungen und Doktorandenzufriedenheit in der deutschsprachigen Rechnungswesen-Forschung. Betriebswirtschaftliche Forschung und Praxis 68: 53-85.

Perrey, Eike, Utz Schäffer, and Sebastian D. Becker. 2012. Struktur und Entwicklung der Rechnungslegungsforschung in deutschen wissenschaftlichen Zeitschriften. Zeitschrift für Betriebswirtschaft 82: 1157-1191.

Perrey, Eike, Utz Schäffer, and Stephan Kramer. 2010. Rechnungslegungsforschung in deutschsprachigen wissenschaftlichen Zeitschriften. Die Betriebswirtschaft 70: 481-494.

Podsakoff, Philip M., Scott B. MacKenzie, Jeong-Yeon Lee, and Nathan Podsakoff. 2003. Common method biases in behavioral research: A critical review of the literature and recommended remedies. Journal of Applied Psychology 88: 879-903.

Power, Michael. 2004. Academics in the accounting policy process: England and Germany compared. In The economics and politics of accounting: International perspectives on trends, policy and practice, ed. Christian Leuz, Dieter Pfaff, and Anthony Hopwood, 376-391. Oxford: Oxford University Press.

Qu, Sandy Q., Shujun Ding, and Shelley M. Lukasewich. 2009. Research the American way: The role of US elites in disseminating and legitimizing Canadian academic accounting research. European Accounting Review 18: 515-569.

Richardson, Alan J. 2015. Quantitative research and the critical accounting project. Critical Perspectives on Accounting 32: 67-77.

Rutherford, Brian A. 2010. The social scientific turn in UK financial accounting research: A philosophical and sociological analysis. Accounting and Business Research 40: 149-171. 
Schäffer, Utz. 2013. Management accounting research in Germany: From splendid isolation to being part of the international community. Journal of Management Control 23: 291-309.

Shackleford, Douglas A., and Terry Shevlin. 2001. Empirical tax research in accounting. Journal of Accounting and Economics 31: 321-387.

Schrader, Ulf, and Thorsten Hennig-Thurau. 2009. VHB-JOURQUAL2: Method, results and implications of the German Academic Association for Business Research's journal ranking. Business Research 2: 180-204.

Schwartz, Bill N., Satina Williams, and Paul F. Williams. 2005. US doctoral students' familiarity with accounting journals: Insights into the structure of the US academy. Critical Perspectives on Accounting 16: 327-348.

Tuttle, Brad, and Jesse Dillard. 2007. Beyond competition: Institutional isomorphism in U.S. accounting research. Accounting Horizons 21: 387-409.

Urdari, Claudia, Vlad A. Porumb, and Ion Anghel. 2015. Training for an international academic career: Structuring a successful $\mathrm{PhD}$ program in Romania. Accounting and Management Information Systems 14: 303-327.

VHB. 2009. Erster Kurs des VHB-Doktorandenprogramms an der Universität Hamburg stattgefunden. Available online: https://web.archive.org/web/20100312042807/http://vhbonline.org/verein/ nachrichten/nachricht-detailansicht/?tx_ttnews[tt_news]=29\&cHash=5a15e13951. Accessed 15 March 2017.

VHB. 2016. The Doctoral Programme. Available online: https://web.archive.org/web/20160822092750/ http://vhbonline.org/en/events/the-doctoral-program/. Accessed 15 March 2017.

Wagenhofer, Alfred. 2006. Management accounting research in German-speaking countries. Journal of Management Accounting Research 18: 1-19.

Wakefield, Robin. 2008. Networks of accounting research: A citation-based structural and net-work analysis. British Accounting Review 40: 228-244.

Waymire, Gregory B. 2012. Seeds of innovation in accounting scholarship. Issues in Accounting Education 27: 1077-1093.

Weber, Jürgen, and Arndt Kaminski. 1995. Zum Promotionsverhalten in der deutschsprachigen Betriebswirtschaftslehre. Ergebnisse einer empirischen Untersuchung. Zeitschrift für betriebswirtschaftliche Forschung 47: 708-725.

Weber, Richard P., and W.C. Stevenson. 1981. Evaluations of accounting journal and department quality. The Accounting Review 56: 596-612.

Williams, Paul F., Gregory J. Jenkins, and Laura Ingraham. 2006. The winnowing away of behavioral accounting research in the US: The process for anointing academic elites. Accounting, Organizations and Society 31: 783-818.

Williams, Paul F., and Jacci L. Rodgers. 1995. The accounting review and the production of accounting knowledge. Critical Perspectives on Accounting 6: 263-287.

Wissenschaftsrat. 2002. Wirtschaftswissenschaftliche Forschung in Deutschland muss international konkurrenzfähig werden. Available online: http://www.wissenschaftsrat.de/download/archiv/pm_ 2502.pdf. Accessed 15 March 2017.

WK RECH. 2015. Qualitative Accounting Research. Available online: http://vhbonline.org/fileadmin/ Kommissionen/WK_RECH/Veranstaltungen/2015_Muenster/Messner_VHB_Muenster_2015.pdf. Accessed 15 March 2017. 